\title{
Article
}

\section{The Impact of the Synergistic Effect of Temperature and Air Pollutants on Chronic Lung Diseases in Subtropical Taiwan}

\author{
Da-Wei Wu ${ }^{1,2,3,4}\left(\mathbb{D}\right.$, Szu-Chia Chen ${ }^{2,4,5,6}{ }^{2}$, Hung-Pin Tu $7 \mathbb{1}$, Chih-Wen Wang ${ }^{2,8}$, Chih-Hsing Hung ${ }^{4,9,10}$, \\ Huang-Chi Chen ${ }^{2,3}{ }^{1}$, Tzu-Yu Kuo ${ }^{2,3}$, Chen-Feng Wang ${ }^{11}$, Bo-Cheng Lai ${ }^{11}$, Pei-Shih Chen 4,12,13,14,* \\ and Chao-Hung Kuo ${ }^{2,15}$
}

Citation: Wu, D.-W.; Chen, S.-C.; Tu, H.-P.; Wang, C.-W.; Hung, C.-H.; Chen, H.-C.; Kuo, T.-Y.; Wang, C.-F.; Lai, B.-C.; Chen, P.-S.; et al. The Impact of the Synergistic Effect of Temperature and Air Pollutants on Chronic Lung Diseases in Subtropical Taiwan. J. Pers. Med. 2021, 11, 819 https: / / doi.org/10.3390/ jpm11080819

Academic Editor: Andreas P. Kalogeropoulos

Received: 4 July 2021

Accepted: 20 August 2021

Published: 21 August 2021

Publisher's Note: MDPI stays neutral with regard to jurisdictional claims in published maps and institutional affiliations.

Copyright: (C) 2021 by the authors Licensee MDPI, Basel, Switzerland. This article is an open access article distributed under the terms and conditions of the Creative Commons Attribution (CC BY) license (https:// creativecommons.org/licenses/by/ $4.0 /)$.
1 Doctoral Degree Program, Department of Public Health, College of Health Sciences, Kaohsiung Medical University, Kaohsiung 807, Taiwan; u8900030@yahoo.com.tw

2 Department of Internal Medicine, Kaohsiung Municipal Siaogang Hospital, Kaohsiung Medical University, Kaohsiung 812, Taiwan; scarchenone@yahoo.com.tw (S.-C.C.); chinwin.wang@gmail.com (C.-W.W.); huangchichen@gmail.com (H.-C.C.); amorfati999@gmail.com (T.-Y.K.); kjh88kmu@gmail.com (C.-H.K.)

3 Division of Pulmonary and Critical Care Medicine, Department of Internal Medicine, Kaohsiung Medical University Hospital, Kaohsiung Medical University, Kaohsiung 807, Taiwan

4 Research Center for Environmental Medicine, Kaohsiung Medical University, Kaohsiung 807, Taiwan; pedhung@gmail.com

5 Division of Nephrology, Department of Internal Medicine, Kaohsiung Medical University Hospital, Kaohsiung Medical University, Kaohsiung 807, Taiwan

6 Faculty of Medicine, College of Medicine, Kaohsiung Medical University, Kaohsiung 807, Taiwan

7 Department of Public Health and Environmental Medicine, School of Medicine, College of Medicine, Kaohsiung Medical University, Kaohsiung 807, Taiwan; p915013@kmu.edu.tw

8 Division of Hepatobiliary, Department of Internal Medicine, Kaohsiung Medical University Hospital, Kaohsiung Medical University, Kaohsiung 807, Taiwan

9 Department of Pediatrics, Kaohsiung Medical University Hospital, Kaohsiung Medical University, Kaohsiung 807, Taiwan

10 Department of Pediatrics, Kaohsiung Municipal Siaogang Hospital, Kaohsiung Medical University, Kaohsiung 807, Taiwan

11 Department of Electronics Engineering, National Yang Ming Chiao Tung University, Hsinchu 300, Taiwan; a114n.d425y@gmail.com (C.-F.W.); bclai@mail.nctu.edu.tw (B.-C.L.)

12 Department of Public Health, College of Health Sciences, Kaohsiung Medical University, Kaohsiung 807, Taiwan

13 Institute of Environmental Engineering, College of Engineering, National Sun Yat-Sen University, Kaohsiung 807, Taiwan

14 Department of Medical Research, Kaohsiung Medical University Hospital, Kaohsiung 807, Taiwan

15 Division of Gastroenterology, Department of Internal Medicine, Kaohsiung Medical University Hospital, Kaohsiung Medical University, Kaohsiung 807, Taiwan

* Correspondence: pschen@kmu.edu.tw; Tel.: +886-7-312-1101 (ext. 2141-34); Fax: +886-7-311-0811

\begin{abstract}
Previous studies have suggested an association between air pollution and lung disease. However, few studies have explored the relationship between chronic lung diseases classified by lung function and environmental parameters. This study aimed to comprehensively investigate the relationship between chronic lung diseases, air pollution, meteorological factors, and anthropometric indices. We conducted a cross-sectional study using the Taiwan Biobank and the Taiwan Air Quality Monitoring Database. A total of 2889 participants were included. We found a V/U-shaped relationship between temperature and air pollutants, with significant effects at both high and low temperatures. In addition, at lower temperatures $\left(<24.6^{\circ} \mathrm{C}\right)$, air pollutants including carbon monoxide (CO) (adjusted OR (aOR):1.78/Log 1 ppb, 95\% CI 0.98-3.25; aOR:5.35/Log 1 ppb, 95\% CI 2.88-9.94), nitrogen monoxide (NO) (aOR:1.05/ppm, 95\% CI 1.01-1.09; aOR:1.11/ppm, 95\% CI 1.07-1.15), nitrogen oxides $\left(\mathrm{NO}_{\mathrm{x}}\right)$ (aOR:1.02/ppm, 95\% CI 1.00-1.05; aOR:1.06/ppm, 95\% CI 1.04-1.08), and sulfur dioxide $\left(\mathrm{SO}_{2}\right)$ (aOR:1.29/ppm, 95\% CI 1.01-1.65; aOR:1.77/ppm, 95\% CI 1.36-2.30) were associated with restrictive and mixed lung diseases, respectively. Exposure to $\mathrm{CO}, \mathrm{NO}, \mathrm{NO}_{2}, \mathrm{NO}_{\mathrm{x}}$ and $\mathrm{SO}_{2}$ significantly affected obstructive and mixed lung disease in southern Taiwan. In conclusion, temperature and air pollution should be considered together when evaluating the impact on chronic lung diseases.
\end{abstract}


Keywords: temperature; air pollution; chronic lung disease

\section{Introduction}

Chronic lung diseases, including obstructive lung diseases (such as asthma, chronic obstructive pulmonary disease (COPD), and bronchiectasis), restrictive lung diseases (such as interstitial lung disease, pulmonary fibrosis and neuromuscular disease), and mixed (obstructive and restrictive) lung disease are diagnosed by spirometry according to the standardized European Respiratory Society/American Thoracic Society guidelines [1]. The United Kingdom Biobank study showed that higher exposure to various air pollutants was significantly associated with lower lung function [2]. In addition, the European Study of Cohorts for Air Pollution Effects (ESCAPE) demonstrated that, even at very low levels, air pollutants had adverse effects on lung function in adults, including both forced expiratory volume in $1 \mathrm{~s}$ (FEV1) and forced vital capacity (FVC) [3]. Moreover, the effect estimates were stronger for FVC than FEV1 for various pollutants, suggesting greater effects on restrictive than obstructive lung diseases [4]. However, a large population-based cohort study also confirmed the relationship between air pollution and incidence of COPD [5]. Air pollution can also induce acute exacerbations of obstructive lung diseases and increase respiratory morbidity and mortality [6]. In addition, acute and chronic air pollution exposure had also been associated with an increased risk of cardiovascular and respiratory morbidity and mortality [7-9]. The use of medical services in patients with chronic diseases had been reported to increase with higher levels of exposure to air pollution [10], especially in industrialized regions [11]. Air pollutants include coarse particulate matter $\left(\mathrm{PM}_{10}\right)$, fine particulate matter $\left(\mathrm{PM}_{2.5}\right)$, carbon monoxide $(\mathrm{CO})$, nitrogen monoxide $(\mathrm{NO})$, nitrogen dioxide $\left(\mathrm{NO}_{2}\right)$, nitrogen oxides $\left(\mathrm{NO}_{\mathrm{x}}\right)$, sulfur dioxide $\left(\mathrm{SO}_{2}\right)$ and ozone $\left(\mathrm{O}_{3}\right)$ can penetrate into the lung parenchyma and alveoli, and induce the production of various inflammatory mediators, such as mitogen-activated protein kinase and nuclear factor kappa-light-chainenhancer of activated B cells (NF- $\mathrm{KB}$ ), which can lead to various chronic lung diseases [12]. In particular, particulate matter (PM) exposure has been associated with acute hospital admissions [13], systemic oxidative damage [14], inflammation [15], and an increased risk of exacerbations and respiratory symptoms in children and adults with existing lung diseases [14,16]. A cumulative effect of $\mathrm{PM}_{2.5}$ and $\mathrm{NO}_{2}$ has been reported prior to disease exacerbations, and high levels of both pollutants have been shown to increase the probability of COPD attacks [17]. Previous studies have confirmed that long-term exposure to fine particles had an effect on airway inflammation in older women. A study reported that exposure to $\mathrm{PM}_{2.5}$ was associated with a higher risk of acute exacerbations of COPD, especially in females and elderly patients (age $>75$ years old), and that this effect was restricted to the cold season (November to April) [18]. In addition, it is recommended that elderly patients with chronic diseases avoid strenuous exercise outdoors when the concentration of outdoor $\mathrm{PM}_{2.5}$ is higher than normal [19]. Furthermore, dynamic changes in air pollutants and meteorological factors coexist simultaneously [20]. Studies from both Northeast Asia and Europe reported that a synergistic effect between high temperature and air pollution may be associated with a higher risk of mortality [21,22]. Hansel et al. reported that an increased risk of mortality in patients with lung diseases (such as COPD) was related to extremely high and low temperatures [23]. In addition, Jo et al. demonstrated that decreasing relative humidity and increasing PM level were associated with significant increases in lung disease-related admissions [24]. In this study, we investigated association among air pollutants, meteorological factors, and chronic lung diseases, and explored the interactions and synergic effects between various air pollutants. 


\section{Materials and Methods}

\subsection{Data Source}

We conducted this cross-sectional study using two large databanks: Taiwan Biobank (TWB) and Taiwan Air Quality Monitoring Database (TAQMD). The TWB was the largest biobank in Taiwan and was directly supported by the government. It is comprised of volunteers with no history of cancer aged between 30 and 70 years. All participants signed informed consent before being included in the TWB, after which they underwent a faceto-face holistic interview, blood sampling, physical examination, and then completed a questionnaire which addressed personal information and lifestyle factors $[25,26]$. The TAQMD was established by the Executive Yuan of the Taiwan Environmental Protection Administration, and is comprised of daily air pollutant concentration data from 74 air quality monitoring stations around Taiwan. TAQMD data was used to establish a connection between the participant's residential area and the location of the nearest air quality monitoring station, then to estimate the outdoor air pollution exposure of each participant, and finally combine the TWB data for further analysis. We also calculated the average concentrations of air pollutants in a selected year, including $\mathrm{PM}_{2.5}, \mathrm{PM}_{10}, \mathrm{CO}, \mathrm{NO}, \mathrm{NO}_{2}$, $\mathrm{NO}_{x}, \mathrm{SO}_{2}$, and $\mathrm{O}_{3}$ using the following three-step method. (1) The corresponding longitude and latitude of the residential address were determined using Google geocoding. (2) The nearest air quality monitoring station was identified from that point as an interpolation point. (3) Data from the mapped station were filtered from the survey date to the previous year, and the average value of each air pollution indicator was calculated.

\subsection{Collection of Demographic, Laboratory and Meteorological Factors}

The following baseline variables were recorded: demographic characteristics (age, sex, smoking, alcohol drinking history), comorbidities (hypertension, type 2 diabetes, renal failure, metabolic syndrome, and coronary artery disease), anthropometric parameters (height, weight, body mass index (BMI), body adiposity indices (BAI), body roundness index (BRI)), biochemical parameters (hematocrit $(\mathrm{Hct})$, albumin, glycohemoglobin $\left(\mathrm{HbA} 1_{\mathrm{C}}\right)$, glutamate pyruvate transaminase (GPT) and creatinine), Taiwan monitoring regions (northern, central, and southern regions), and meteorological factors (temperature $\left({ }^{\circ} \mathrm{C}\right)$, relative humidity $(\%)$, and rainfall $(\mathrm{mm}))$.

\subsection{Assessment of Lung Function Status}

The lung function parameters in the Taiwan Biobank include forced expiratory volume in one second (FEV1), forced vital capacity (FVC), FEV1/FVC\% ratio, FVC-predicted value, and FEV1-predicted value. FVC-predicted and FEV1-predicted values were determined by dividing the measured value by the reference value, which was calculated from a formula derived from the general population based on gender, age, height, and Asian ethnicity. The spirometry measurements were performed by well-trained technicians using the MicroLab spirometer and Spida 5 software (Micro Medical Ltd., Rochester, Kent, UK) [27]. We defined chronic lung diseases in terms of three abnormal types of lung function, including obstructive lung diseases (FEV1/FVC $<70 \%$, such as asthma, chronic obstructive pulmonary disease, and bronchiectasis), restrictive lung diseases (FEV1/FVC $>70 \%$ and FVC $<80 \%$, such as interstitial lung disease, neuromuscular disease, and obesity), and mixed (obstructive and restrictive) lung disease, according to the standardized European Respiratory Society/American Thoracic Society guidelines [1].

\subsection{Ethics Statement}

This study was approved by the Institutional Review Board of the Affiliated Hospital of Kaohsiung Medical University (KMUHIRB-E(I)-20180242). In accordance with institutional requirements and the principles of the Declaration of Helsinki, written informed consent was obtained from each participant. The TWB has obtained ethics certification from the Review Board/IRB-BM of the Taiwan Academy of Biomedical Sciences and the Taiwan TWB Ethics and Governance Committee. 


\subsection{Statistical Analysis}

Descriptive results were analyzed between spirometry groups using one-way ANOVA and chi-squared/Fisher's exact tests, as appropriate. Cramer's V test was used to describe the magnitude of the association between categorical variables for a contingency table larger than $2 \times 2$. Spearman's rank correlation was used to measure the strength of the relationship between two continuous variables. Crude odds ratios (ORs) and $95 \%$ confidence intervals (CIs) were estimated using multinomial logistic regression. Adjusted ORs and 95\% CIs were estimated using stepwise multinomial logistic regression, and were used to identify the covariant factors associated with the development of lung diseases (spirometry groups) when the factors showed a significant association in the crude analysis. Interactions between meteorological factors and air pollution factors and between monitoring area and air pollution factors were tested according to the significance of the interaction term in the multinomial logistic regression analysis. After confirming data consistency, continuous variables, such as pollution factors that were not normally distributed, were log-transformed to achieve normality before statistical analysis. All data analyses were performed using SAS software version 9.4 (SAS Institute Inc., Cary, NC, USA).

\section{Results}

\subsection{Descriptive Statistics of the Demographic, Laboratory, Meteorological Factors and Air Pollutants}

The mean age of the 2889 enrolled participants was $50.14 \pm 10.64$ years. Of these participants, $1323(45.8 \%)$ were men and $1566(54.2 \%)$ were women. The participants were stratified into four groups according to lung function test results: control group (normal spirometry group), and three chronic lung disease groups (obstructive group, restrictive group, and mixed group). There were no obvious differences with respect to smoking and alcohol consumption among the groups. In addition, when compared with the normal spirometry group, we found that factors associated with higher risk of chronic lung diseases include elderly age ( $>60$ years), female gender, lower body height and weight, higher body adiposity index and body roundness index, lower haematocrit, higher glycohemoglobin, and lower albumin level (Table 1). These results were confirmed by post hoc analysis (Table $\mathrm{S} 1$ ). In addition, exposure to $\mathrm{CO}, \mathrm{NO}, \mathrm{NO}_{2}, \mathrm{NO}_{\mathrm{x}}$ and $\mathrm{SO}_{2}$ in the environment increased the systemic impact on the patients with chronic lung diseases, especially in mixed lung disease (Table 1). With regards to the baseline characteristics of air pollution factors and meteorological factors, the lowest and highest average annual temperatures were $21.46{ }^{\circ} \mathrm{C}$ and $26.36{ }^{\circ} \mathrm{C}$ (average, $24.33{ }^{\circ} \mathrm{C}$ ), respectively. The lowest, highest and average levels of all air pollutants and meteorological measures were presented on Table S2.

\subsection{Correlation between Meteorological Factors and Outdoor Air Pollutants}

We found that temperature was positively correlated with $\mathrm{PM}_{2.5}, \mathrm{PM}_{10}, \mathrm{O}_{3}$, and $\mathrm{SO}_{2}$ concentrations. Relative humidity was negatively correlated with other meteorological factors and air pollutants except for temperature and $\mathrm{O}_{3}$ levels. $\mathrm{PM}_{2.5}$ concentrations was positively correlated with all meteorological factors except for relative humidity, and all air pollutants except for $\mathrm{O}_{3}$ and NO. Except for $\mathrm{PM}_{2.5}$ and $\mathrm{PM}_{10}, \mathrm{CO}$ had very high correlations with all air pollutants (especially $\mathrm{NO}, \mathrm{NO}_{2}$, and $\mathrm{NO}_{\mathrm{x}}$ ). In addition, there was a moderate negative correlation between $\mathrm{CO}$ and $\mathrm{O}_{3}$. (Table S3). 
Table 1. Descriptive statistics of the demographic, laboratory, meteorological factors, and air pollutants.

\begin{tabular}{|c|c|c|c|c|c|c|}
\hline & Total & $\begin{array}{c}\text { Normal } \\
\text { Spirometry(1) }\end{array}$ & $\begin{array}{l}\text { Obstructive } \\
\text { Impair- } \\
\text { ment(2) }\end{array}$ & $\begin{array}{l}\text { Restrictive } \\
\text { Impair- } \\
\text { ment(3) }\end{array}$ & $\begin{array}{l}\text { Mixed Impair- } \\
\text { ment(4) }\end{array}$ & $p$-Value \\
\hline$n$ & 2889 & 1902 & 733 & 154 & 100 & \\
\hline Age (years), mean (SD) & $50.14(10.64)$ & $49.51(10.46)$ & $50.56(10.68)$ & $52.61(11.02)$ & $55.31(11.25)$ & $<0.0001$ \\
\hline $30-39$ & $628(21.7)$ & $438(23.0)$ & $149(20.3)$ & $26(16.9)$ & $15(15.0)$ & \\
\hline $40-49$ & $760(26.3)$ & $524(27.5)$ & $186(25.4)$ & $37(24.0)$ & $13(13.0)$ & \\
\hline $40-59$ & $891(30.8)$ & $585(30.8)$ & $231(31.5)$ & $49(31.8)$ & $26(26.0)$ & \\
\hline$\geq 60$ & $610(21.1)$ & $355(18.7)$ & $167(22.8)$ & $42(27.3)$ & $46(46.0)$ & $<0.0001$ \\
\hline \multicolumn{7}{|l|}{ Sex, $n(\%)$} \\
\hline Male & $1323(45.8)$ & $903(47.5)$ & $322(43.9)$ & $66(42.9)$ & $32(32.0)$ & \\
\hline Female & $1566(54.2)$ & $999(52.5)$ & $411(56.1)$ & $88(57.1)$ & $68(68.0)$ & 0.0098 \\
\hline \multicolumn{7}{|l|}{ Smoking, $n(\%)$} \\
\hline None & $2112(73.1)$ & $1382(72.7)$ & $535(73)$ & $116(75.3)$ & $79(79.0)$ & \\
\hline Current \& Former & $777(26.9)$ & $520(27.3)$ & $198(27)$ & $38(24.7)$ & $21(21.0)$ & 0.5031 \\
\hline \multicolumn{7}{|l|}{ Alcohol consumption, $n(\%)$} \\
\hline None \& sometimes & $2605(90.2)$ & $1711(90.0)$ & $660(90.0)$ & $143(92.9)$ & $91(91.0)$ & \\
\hline Quit & $67(2.3)$ & $47(2.5)$ & $16(2.2)$ & $4(2.6)$ & $0(0.0)$ & \\
\hline Current & $217(7.5)$ & $144(7.6)$ & $57(7.8)$ & $7(4.5)$ & $9(9.0)$ & 0.5520 \\
\hline \multicolumn{7}{|l|}{ Anthropometric parameter, mean (SD) } \\
\hline Height $(\mathrm{cm})$ & $162.63(8.26)$ & $163.09(8.32)$ & $162.52(8.05)$ & $160.26(7.57)$ & $158.28(7.80)$ & $<0.0001$ \\
\hline Weight $(\mathrm{kg})$ & $64.10(12.10)$ & $64.49(12.22)$ & $64.08(11.6)$ & $62.74(12.94)$ & $58.82(10.67)$ & $<0.0001$ \\
\hline Body Mass Index mean $\left(\mathrm{kg} / \mathrm{m}^{2}\right)$ & $24.12(3.45)$ & $24.13(3.44)$ & $24.16(3.32)$ & $24.34(4.22)$ & $23.38(3.27)$ & 0.1457 \\
\hline Body Adiposity Index & $28.60(3.92)$ & $28.40(3.92)$ & $28.75(3.79)$ & $29.62(4.38)$ & $29.72(3.79)$ & $<0.0001$ \\
\hline Body Roundness Index & $3.72(1.13)$ & $3.70(1.12)$ & $3.74(1.08)$ & $3.96(1.38)$ & $3.70(1.20)$ & 0.0475 \\
\hline \multicolumn{7}{|l|}{ Biochemical data, mean (SD) } \\
\hline Hematocrit $(\%)$ & $44.15(4.61)$ & $44.32(4.64)$ & $43.86(4.61)$ & $44.13(4.52)$ & $43.10(3.86)$ & 0.0139 \\
\hline Glycohemoglobin (\%) & $5.78(0.79)$ & $5.73(0.71)$ & $5.84(0.90)$ & $6.00(1.13)$ & $5.82(0.73)$ & $<0.0001$ \\
\hline Albumin (g/dL) & $4.60(0.24)$ & $4.60(0.24)$ & $4.6(0.24)$ & $4.56(0.25)$ & $4.54(0.24)$ & 0.0241 \\
\hline $\begin{array}{l}\text { Serum glutamic pyruvic } \\
\text { Transaminase (IU/L) }\end{array}$ & $24.91(22.64)$ & $24.84(22.51)$ & $24.93(24.01)$ & $27.45(22.79)$ & $22.25(11.92)$ & 0.3416 \\
\hline Creatinine (mg/dL) & $0.76(0.44)$ & $0.77(0.50)$ & $0.75(0.32)$ & $0.72(0.22)$ & $0.68(0.16)$ & 0.0534 \\
\hline \multicolumn{7}{|l|}{ Comorbidities, $n(\%)$} \\
\hline Hypertension & $309(10.7)$ & $197(10.4)$ & $78(10.6)$ & $23(14.9)$ & $11(11.0)$ & 0.3662 \\
\hline Diabetes mellitus type 2 & $138(4.8)$ & $77(4.0)$ & $43(5.9)$ & $12(7.8)$ & $6(6.0)$ & 0.0474 \\
\hline Renal failure & $4(0.1)$ & $3(0.2)$ & $1(0.1)$ & $0(0.0)$ & $0(0.0)$ & 1.0000 \\
\hline Metabolic syndrome & $525(18.2)$ & $339(17.8)$ & $136(18.6)$ & $36(23.4)$ & $14(14.0)$ & 0.2503 \\
\hline Coronary artery disease & $29(1.0)$ & $21(1.1)$ & $6(0.8)$ & $2(1.3)$ & $0(0.0)$ & 0.7713 \\
\hline \multicolumn{7}{|l|}{ Monitoring region, $n(\%)$} \\
\hline Northern region & $571(19.8)$ & $312(16.4)$ & $182(24.8)$ & $36(23.4)$ & $41(41.0)$ & \\
\hline Central region & $558(19.3)$ & $390(20.5)$ & $139(19.0)$ & $21(13.6)$ & $8(8.0)$ & \\
\hline Southern region & $1760(60.9)$ & $1200(63.1)$ & $412(56.2)$ & $97(63.0)$ & $51(51.0)$ & $<0.0001$ \\
\hline \multicolumn{7}{|l|}{ Environmental factors, mean (SD) } \\
\hline Temperature $\left({ }^{\circ} \mathrm{C}\right)$ & $24.33(0.77)$ & $24.31(0.72)$ & $24.41(0.84)$ & $24.36(0.93)$ & $24.18(1.04)$ & 0.0040 \\
\hline Relative humidity (\%) & $74.29(2.45)$ & $74.2(2.47)$ & $74.51(2.37)$ & $74.22(2.49)$ & $74.57(2.47)$ & 0.0157 \\
\hline Rainfall (mm/day) & $0.22(0.05)$ & $0.22(0.05)$ & $0.21(0.05)$ & $0.23(0.05)$ & $0.23(0.05)$ & $<0.0001$ \\
\hline \multicolumn{7}{|l|}{ Air pollution factors, mean (SD) } \\
\hline $\mathrm{PM}_{10}(\mu \mathrm{g} / \mathrm{m} 3)$ & $68.07(17.06)$ & $69.05(16.99)$ & $65.72(17.51)$ & $68.5(14.8)$ & $65.97(16.56)$ & $<0.0001$ \\
\hline $\mathrm{PM}_{2.5}(\mu \mathrm{g} / \mathrm{m} 3)$ & $37.65(10.74)$ & $38.44(10.74)$ & $35.88(10.74)$ & $38.36(10.15)$ & $34.45(9.56)$ & $<0.0001$ \\
\hline $\mathrm{CO}(\mathrm{ppm})$ & $0.45(0.18)$ & $0.44(0.17)$ & $0.45(0.20)$ & $0.48(0.19)$ & $0.54(0.26)$ & $<0.0001$ \\
\hline $\mathrm{NO}(\mathrm{ppb})$ & $4.18(4.01)$ & $4.00(3.64)$ & $4.31(4.29)$ & $4.46(4.57)$ & $6.21(6.34)$ & $<0.0001$ \\
\hline $\mathrm{NO}_{2}(\mathrm{ppb})$ & $14.98(5.65)$ & $14.9(5.23)$ & $14.76(6.45)$ & $15.77(5.33)$ & $16.9(6.89)$ & 0.0011 \\
\hline $\mathrm{NO}_{X}(\mathrm{ppb})$ & $19.14(8.93)$ & $18.88(8.19)$ & $19.06(9.94)$ & $20.21(9.23)$ & $23.09(12.45)$ & $<0.0001$ \\
\hline $\mathrm{O}_{3}(\mathrm{ppb})$ & $30.91(3.86)$ & $30.94(3.78)$ & $31.04(4.04)$ & $30.71(3.63)$ & $29.54(4.20)$ & 0.0028 \\
\hline $\mathrm{SO}_{2}(\mathrm{ppb})$ & $3.66(1.20)$ & $3.61(1.09)$ & $3.70(1.39)$ & $3.82(1.20)$ & $4.00(1.42)$ & 0.0017 \\
\hline
\end{tabular}

Characteristics of the study participants for the continuous and categorical variables were analyzed using one-way ANOVA and the chi-squared/Fisher's exact test, as appropriate, for comparisons among spirometry groups. SD: Standard deviation; PM 2.5 : Fine particulate

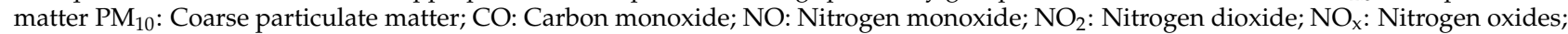
$\mathrm{O}_{3}$ : Ozone; $\mathrm{SO}_{2}$ : Sulfur dioxide.

\subsection{Associations between Chronic Lung Disease and All Factors}

Table S4 shows the crude ORs of all factors in the three chronic lung disease groups compared with the normal group. In the obstructive group, more of the participants were $\geq 60$ years old, had lower Hct levels, higher BAI and HbA1c values, and more had type 2 diabetes as a comorbidity. In the restrictive group, more of the participants were aged 
$\geq 60$ years, had lower body height, higher BAI, BRI and $\mathrm{HbA1c}$ values, and more had type 2 diabetes. In the mixed group, more of the participants were female and aged $\geq 60$ years, had lower body height and weight, higher BAI, and lower albumin level.

Table 2 shows the adjusted ORs of all factors. In the obstructive group, multivariate analysis identified five independent predictive factors: $\mathrm{HbA1c}$ (OR 1.13; 95\% CI 1.01-1.27; $p=0.0312$ ), southern region (OR $0.61 ; 95 \%$ CI $0.39-0.97 ; p=0.0351$ ), temperature (OR 1.58; 95\% CI 1.35-1.86; $p<0.0001$ ), relative humidity (OR 1.06; 95\% CI 1.01-1.11; $p=0.0104$ ), and $\mathrm{SO}_{2}(\mathrm{OR} 1.26 ; 95 \%$ CI $1.09-1.45 ; p=0.0015)$.

Table 2. Stepwise multinomial logistic regression analysis.

\begin{tabular}{|c|c|c|c|c|c|c|}
\hline & Obstructive vs. Normal & & Restrictive vs. Normal & & Mixed vs. Normal & \\
\hline & Adjusted OR (95\% CI) & $p$ & Adjusted OR (95\% CI) & $p$ & Adjusted OR (95\% CI) & $p$ \\
\hline \multicolumn{7}{|l|}{ Age group (years) } \\
\hline $30-39$ & 1.00 & & 1.00 & & 1.00 & \\
\hline $40-49$ & $1.00(0.77-1.3)$ & 0.9876 & $1.11(0.65-1.89)$ & 0.6944 & $0.65(0.3-1.42)$ & 0.2809 \\
\hline $40-59$ & $0.98(0.76-1.27)$ & 0.8847 & $1.08(0.64-1.81)$ & 0.7836 & $0.89(0.44-1.8)$ & 0.7546 \\
\hline$\geq 60$ & $1.15(0.86-1.54)$ & 0.3385 & $1.38(0.80-2.39)$ & 0.2532 & $2.64(1.35-5.13)$ & 0.0043 \\
\hline \multicolumn{7}{|l|}{ Gender } \\
\hline Male & 1.00 & & 1.00 & & 1.00 & \\
\hline Female & - & & - & & - & - \\
\hline \multicolumn{7}{|l|}{$\begin{array}{l}\text { Anthropometric } \\
\text { parameters }\end{array}$} \\
\hline Height & $0.99(0.98-1.01)$ & 0.2861 & $0.96(0.94-0.98)$ & $<0.0001$ & $0.93(0.91-0.96)$ & $<0.0001$ \\
\hline Weight & - & & - & & - & - \\
\hline Body Adiposity Index & - & & - & & - & - \\
\hline Body Roundness Index & - & & - & & - & - \\
\hline \multicolumn{7}{|l|}{ Biochemical data } \\
\hline Hematocrit & - & & - & & - & - \\
\hline Glycohemoglobin & $1.13(1.01-1.27)$ & 0.0312 & $1.28(1.09-1.51)$ & 0.0028 & $0.94(0.69-1.28)$ & 0.7093 \\
\hline Albumin & - & & - & & - & - \\
\hline Creatinine & - & & - & & - & - \\
\hline \multicolumn{7}{|l|}{ Comorbidities } \\
\hline Diabetes mellitus type 2 & - & & - & & - & - \\
\hline \multicolumn{7}{|l|}{ Monitoring region } \\
\hline Northern region & 1.00 & & 1.00 & & 1.00 & \\
\hline Central region & $0.94(0.59-1.50)$ & 0.7913 & $0.32(0.13-0.78)$ & 0.0124 & $0.07(0.02-0.24)$ & $<0.0001$ \\
\hline Southern region & $0.61(0.39-0.97)$ & 0.0351 & $0.31(0.13-0.74)$ & 0.0083 & $0.14(0.05-0.44)$ & 0.0007 \\
\hline \multicolumn{7}{|l|}{ Meteorological factors } \\
\hline Temperature & $1.58(1.35-1.86)$ & $<0.0001$ & $1.30(0.96-1.77)$ & 0.0906 & $1.87(1.26-2.77)$ & 0.0020 \\
\hline Relative humidity & $1.06(1.01-1.11)$ & 0.0104 & 1.07 (0.99-1.16) & 0.0870 & $1.15(1.03-1.28)$ & 0.0108 \\
\hline Rainfall & - & & - & & - & - \\
\hline \multicolumn{7}{|l|}{ Air pollution factors } \\
\hline $\mathrm{PM}_{10}$ & - & & - & & - & - \\
\hline $\mathrm{PM}_{2.5}$ & $0.97(0.96-0.99)$ & 0.0002 & $1.00(0.97-1.03)$ & 0.9868 & $0.97(0.93-1.01)$ & 0.0930 \\
\hline $\mathrm{CO}$ & $1.19(0.45-3.14)$ & 0.7219 & $20.3(3.14-131.12)$ & 0.0016 & $0.87(0.08-9.77)$ & 0.9122 \\
\hline $\mathrm{NO}$ & - & & - & & - & - \\
\hline $\mathrm{NO}_{2}$ & $1.01(0.91-1.13)$ & 0.8136 & 1.39 (1.14-1.7) & 0.0012 & $1.58(1.25-1.99)$ & 0.0001 \\
\hline $\mathrm{NO}_{X}$ & $0.98(0.91-1.06)$ & 0.6126 & $0.76(0.66-0.87)$ & 0.0001 & $0.86(0.73-1.02)$ & 0.0809 \\
\hline $\mathrm{O}_{3}$ & - & & - & & - & - \\
\hline $\mathrm{SO}_{2}$ & $1.26(1.09-1.45)$ & 0.0015 & $0.91(0.68-1.22)$ & 0.5256 & $0.80(0.56-1.13)$ & 0.2058 \\
\hline
\end{tabular}

OR: odds ratio; CI: confidence interval; SD: Standard deviation; CO: Carbon monoxide; NO: Nitrogen monoxide; $\mathrm{NO}_{2}$ : Nitrogen dioxide; $\mathrm{NO}_{\mathrm{x}}$ : Nitrogen oxides; $\mathrm{O}_{3}$ : Ozone; $\mathrm{SO}_{2}$ : Sulfur dioxide; $\mathrm{PM}_{10}$ : coarse particulate matter; $\mathrm{PM}_{2.5}$ : fine particulate matter. Data for CO were skewed and log transformed for analysis.

In the restrictive group, multivariate analysis identified seven independent predictive factors: height (OR 0.96; 95\% CI 0.94-0.98; $p<0.0001$ ), HbA1c (OR 1.28; 95\% CI 1.09-1.51; $p=0.0028)$, central region (OR $0.32 ; 95 \%$ CI $0.13-0.78 ; p=0.0124)$, southern region (OR 0.31; $95 \%$ CI $0.13-0.74 ; p=0.0083), \mathrm{CO}(\mathrm{OR} 511.99 ; 95 \%$ CI 8.08-32,425.36; $p=0.0032), \mathrm{NO}_{2}(\mathrm{OR}$ $1.39 ; 95 \%$ CI 1.14-1.70; $p=0.0012)$, and $\mathrm{NO}_{\mathrm{x}}(\mathrm{OR} 0.76 ; 95 \% \mathrm{CI} 0.66-0.87 ; p=0.0001)$. In the mixed group, multivariate analysis identified seven independent predictive factors: age $\geq 60$ years (OR 2.64; 95\% CI 1.35-5.13; $p<0.0043$ ), height (OR 0.93; 95\% CI 0.91-0.96; $p<0.0001$ ), central region (OR $0.07 ; 95 \%$ CI $0.02-0.24 ; p<0.0001$ ), southern region (OR 0.14; $95 \%$ CI $0.05-0.44 ; p=0.0007)$, temperature (OR 1.87; 95\% CI 1.28-2.77; $p=0.0020)$, relative 
humidity (OR 1.15; 95\% CI 1.03-1.28; $p=0.0108$ ), and $\mathrm{NO}_{2}$ (OR 1.58; 95\% CI 1.25-1.99; $p=0.0001$ ). Compared with the northern region, the participants in the southern and central regions seemed less likely to suffer from chronic lung diseases. However, after adjusting for temperature and monitoring region, opposite results were obtained.

\subsection{Interactions between Temperature and Air Pollutants}

Figure 1 shows a graph of relationship among air pollutants and temperature; in most graphs, the curve of the normal group was lower than the other three chronic lung diseases groups. In the graphs of $\mathrm{CO}, \mathrm{NO}, \mathrm{NO}_{2}, \mathrm{NO}_{\mathrm{x}}$ and $\mathrm{SO}_{2}$, there was a $\mathrm{V} / \mathrm{U}$-shaped curve between temperature and air pollutants. When the temperature was at the lowest or highest, the concentrations of these air pollutants were at the highest, but at around 24.3-24. ${ }^{\circ} \mathrm{C}$ (optimum temperature), their concentrations were the lowest. However, the findings for $\mathrm{O}_{3}$ were the opposite, and at the highest or lowest temperature, the $\mathrm{O}_{3}$ concentration was the lowest, whereas at around $24.9^{\circ} \mathrm{C}$ the concentration was the highest. In addition, the concentrations of $\mathrm{PM}_{2.5}$ and $\mathrm{PM}_{10}$ elevated with increasing temperature.

This shows a graph of air pollutants and temperature, with the horizontal axis showing temperature and the vertical axis showing the various air pollutants. The purple curve represents the distribution of the normal population under air pollution and temperature, the pink line represents the obstructive lung disease group, the green line represents the restrictive lung disease group, and the brown line represents the mixed-type lung disease group temperature. These findings indicated that temperature may be a key factor mediating the interactions.

\subsection{Interactions between Temperature and Monitoring Regions}

Table S5 confirms the interactions between temperature and monitoring region, temperature and air pollutants, and monitoring region and air pollutants in three chronic lung disease groups. We found a moderate relationship between monitoring region and temperature by the Cramer's V analysis on Table S6, and the impact of air pollutants seemed to be consistent between the northern and central regions; therefore, we combined the northern and central regions into one group and compared it with the southern region group later.

\subsection{Correlations between Temperature and Air Pollutants}

We selected different turning points to divide the temperatures into higher and lower temperature groups in the different air pollutant groups (Table S7). Due to the CO data being skewed, log transformation was carried out before further analysis. Table 3 shows the final relationships between temperature and the effect of air pollutants. Interestingly, lower temperatures had a greater effect on air pollutant concentrations, and this finding was consistent in restrictive and mixed lung disease groups. Although we found the same phenomenon at higher temperatures, the effect was not as strong as that at lower temperatures. In comparisons of the restrictive lung disease group with the normal group: for CO exposure, OR 1.78 and 95\% CI 0.98-3.25; for NO exposure, OR 1.05 and 95\% CI 1.01-1.09; for $\mathrm{NO}_{x}$ exposure, OR 1.02 and $95 \%$ CI 1.00-1.05; and for $\mathrm{SO}_{2}$ exposure, OR 1.29 and $95 \%$ CI 1.01-1.65. In comparisons of the mixed-type lung disease group with the normal group: for CO exposure, OR 5.35 and 95\% CI 2.88-9.94; for NO exposure, OR 1.11 and $95 \% \mathrm{CI} 1.07-1.15$; for $\mathrm{NO}_{2}$ exposure, OR 1.13 and $95 \% \mathrm{CI} 1.08-1.19$; for $\mathrm{NO}_{\mathrm{x}}$ exposure, OR 1.06 and 95\% CI 1.04-1.08; and for $\mathrm{SO}_{2}$ exposure, OR 1.77 and 95\% CI 1.36-2.30. When comparing the obstructive lung disease group with the normal group at lower temperatures, the results showed: for NO exposure, OR 1.03 and 95\% CI 1.01-1.06; and for $\mathrm{NO}_{\mathrm{x}}$ exposure, OR 1.01 and $95 \%$ CI $1.00-1.03$.

In Table 4, we found that the southern region of Taiwan had a significant impact on air pollution in the obstructive and mixed lung disease group. However, in the northern and central region groups, we only found this association in the mixed lung disease group. In southern Taiwan, comparisons between the obstructive lung disease group and the 
normal group showed: for CO exposure, OR 4.17 and 95\% CI 2.08-8.37; for NO exposure, OR 1.28 and 95\% CI 1.15-1.44; for $\mathrm{NO}_{2}$ exposure, OR 1.13 and 95\% CI 1.08-1.18); for $\mathrm{NO}_{x}$ exposure, OR 1.09 and $95 \% \mathrm{CI} 1.06-1.13$; and for $\mathrm{SO}_{2}$ exposure, OR 1.65 and $95 \%$ CI 1.45-1.89. Comparisons of the mixed-type lung disease group with the normal group showed: for CO exposure, OR 18.85 and 95\% CI 3.53-100.59; for NO exposure, OR 1.33 and 95\% CI 1.02-1.73; for $\mathrm{NO}_{2}$ exposure OR 1.25 and 95\% CI 1.13-1.37; for $\mathrm{NO}_{x}$ exposure, OR 1.16 and $95 \% \mathrm{CI} 1.08-1.25$, and for $\mathrm{SO}_{2}$ exposure, OR 1.83 and $95 \%$ CI 1.40-2.38. Exposures to $\mathrm{PM}_{2.5}, \mathrm{PM}_{10}$, and $\mathrm{O}_{3}$ were not associated with any demographic, clinical, or spiro-metric characteristics. Comparisons of the restrictive lung disease group with the normal group showed: for CO exposure, OR 11.58 and 95\% CI 3.29-40.81; for $\mathrm{NO}_{2}$ exposure, OR 1.09 and 95\% CI 1.01-1.18; and for $\mathrm{SO}_{2}$ exposure, OR 1.29 and 95\% CI 1.00-1.65.
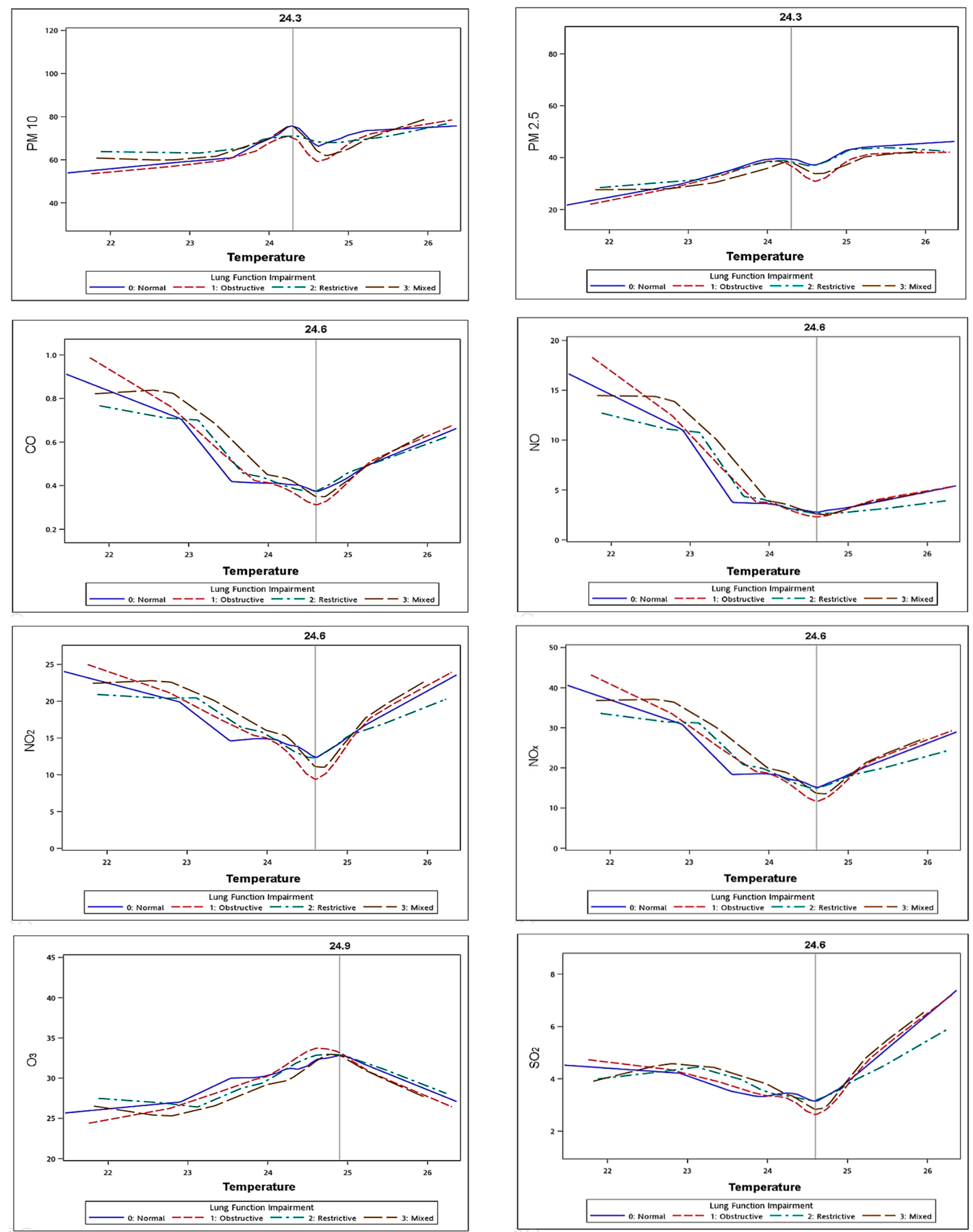

Figure 1. Plot of Temperature and Air pollutants in four groups. 
Table 3. Interactions between temperature and air pollutants.

\begin{tabular}{|c|c|c|c|c|c|c|c|c|c|c|c|c|}
\hline & \multicolumn{6}{|c|}{ Low Temperature } & \multicolumn{6}{|c|}{ High Temperature } \\
\hline & $\begin{array}{l}\text { Obstructive } \\
\text { vs. Normal }\end{array}$ & & $\begin{array}{l}\text { Restrictive } \\
\text { vs. Normal }\end{array}$ & & $\begin{array}{c}\text { Mixed vs. } \\
\text { Normal }\end{array}$ & & $\begin{array}{l}\text { Obstructive } \\
\text { vs. Normal }\end{array}$ & & $\begin{array}{l}\text { Restrictive } \\
\text { vs. Normal }\end{array}$ & & $\begin{array}{c}\text { Mixed vs. } \\
\text { Normal }\end{array}$ & \\
\hline & $\begin{array}{c}\text { Adjusted } \\
\text { OR }(95 \% \text { CI) }\end{array}$ & $p$ & $\begin{array}{c}\text { Adjusted } \\
\text { OR (95\% CI) }\end{array}$ & $p$ & $\begin{array}{c}\text { Adjusted } \\
\text { OR }(95 \% \text { CI) }\end{array}$ & $p$ & $\begin{array}{c}\text { Adjusted } \\
\text { OR (95\% CI) }\end{array}$ & $p$ & $\begin{array}{c}\text { Adjusted } \\
\text { OR }(95 \% \text { CI) }\end{array}$ & $p$ & $\begin{array}{c}\text { Adjusted } \\
\text { OR (95\% CI) }\end{array}$ & $p$ \\
\hline $\mathrm{PM}_{10}$ & $\begin{array}{c}0.99 \\
(0.98-0.99)\end{array}$ & 0.0084 & $\begin{array}{c}0.99 \\
(0.97-1.01)\end{array}$ & 0.3815 & $\begin{array}{c}0.98 \\
(0.96-1.01)\end{array}$ & 0.1297 & $\begin{array}{c}0.99 \\
(0.99-1.00)\end{array}$ & 0.1169 & $\begin{array}{c}1.01 \\
(0.99-1.02)\end{array}$ & 0.1942 & $\begin{array}{c}1.01 \\
(0.99-1.02)\end{array}$ & 0.5185 \\
\hline $\mathrm{PM}_{2.5}$ & $\begin{array}{c}0.98 \\
(0.96-0.99)\end{array}$ & 0.0133 & $\begin{array}{c}0.97 \\
(0.93-1.00)\end{array}$ & 0.0845 & $\begin{array}{c}0.87 \\
(0.82-0.93)\end{array}$ & $<0.0001$ & $\begin{array}{c}0.98 \\
(0.97-0.99)\end{array}$ & 0.0015 & $\begin{array}{c}1.02 \\
(1.00-1.04)\end{array}$ & 0.0458 & $\begin{array}{c}1.00 \\
(0.98-1.02)\end{array}$ & 0.9675 \\
\hline $\mathrm{CO}$ & $\begin{array}{c}1.21 \\
(0.88-1.66)\end{array}$ & 0.2421 & $\begin{array}{c}1.78 \\
(0.98-3.25)\end{array}$ & 0.0596 & $\begin{array}{c}5.35 \\
(2.88-9.94)\end{array}$ & $<0.0001$ & $\begin{array}{c}0.93 \\
(0.63-1.39)\end{array}$ & 0.7307 & $\begin{array}{c}4.21 \\
(1.77-9.99)\end{array}$ & 0.0011 & $\begin{array}{c}2.07 \\
(0.84-5.11)\end{array}$ & 0.1163 \\
\hline $\mathrm{NO}$ & $\begin{array}{c}1.03 \\
(1.01-1.06)\end{array}$ & 0.0041 & $\begin{array}{c}1.05 \\
(1.01-1.09)\end{array}$ & 0.0137 & $\begin{array}{c}1.11 \\
(1.07-1.15)\end{array}$ & $<0.0001$ & $\begin{array}{c}1.06 \\
(0.94-1.18)\end{array}$ & 0.3491 & $\begin{array}{c}0.86 \\
(0.69-1.06)\end{array}$ & 0.1604 & $\begin{array}{c}1.14 \\
(0.87-1.49)\end{array}$ & 0.3313 \\
\hline $\mathrm{NO}_{2}$ & $\begin{array}{c}1.02 \\
(0.99-1.04)\end{array}$ & 0.2000 & $\begin{array}{c}1.04 \\
(0.99-1.09)\end{array}$ & 0.0659 & $\begin{array}{c}1.13 \\
(1.08-1.19)\end{array}$ & $<0.0001$ & $\begin{array}{c}1.00 \\
(0.98-1.03)\end{array}$ & 0.7627 & $\begin{array}{c}1.06 \\
(1.01-1.12)\end{array}$ & 0.0251 & $\begin{array}{c}1.07 \\
(1.00-1.14)\end{array}$ & 0.0406 \\
\hline $\mathrm{NO}_{x}$ & $\begin{array}{c}1.01 \\
(1.00-1.03)\end{array}$ & 0.0312 & $\begin{array}{c}1.02 \\
(1.00-1.05)\end{array}$ & 0.0252 & $\begin{array}{c}1.06 \\
(1.04-1.08)\end{array}$ & $<0.0001$ & $\begin{array}{c}1.01 \\
(0.98-1.03)\end{array}$ & 0.6624 & $\begin{array}{c}1.04 \\
(0.99-1.08)\end{array}$ & 0.1144 & $\begin{array}{c}1.05 \\
(0.99-1.11)\end{array}$ & 0.0582 \\
\hline $\mathrm{O}_{3}$ & $\begin{array}{c}0.88 \\
(0.83-0.93)\end{array}$ & 0.8177 & $\begin{array}{c}0.97 \\
(0.92-1.02)\end{array}$ & 0.2219 & $\begin{array}{c}0.88 \\
(0.83-0.93)\end{array}$ & $<0.0001$ & $\begin{array}{c}0.88 \\
(0.75-1.03)\end{array}$ & 0.0008 & $\begin{array}{c}0.98 \\
(0.87-1.11)\end{array}$ & 0.7681 & $\begin{array}{c}0.88 \\
(0.75-1.03)\end{array}$ & 0.1116 \\
\hline $\mathrm{SO}_{2}$ & $\begin{array}{c}1.04 \\
(0.92-1.19)\end{array}$ & 0.5211 & $\begin{array}{c}1.29 \\
(1.01-1.65)\end{array}$ & 0.0402 & $\begin{array}{c}1.77 \\
(1.36-2.30)\end{array}$ & $<0.0001$ & $\begin{array}{c}1.12 \\
(1.00-1.24)\end{array}$ & 0.0426 & $\begin{array}{c}1.17 \\
(0.96-1.41)\end{array}$ & 0.1189 & $\begin{array}{c}1.38 \\
(1.08-1.78)\end{array}$ & 0.0104 \\
\hline
\end{tabular}

Adjusted ORs and 95\% CIs were estimated using multinomial logistic regression after categorization by age, height, white blood cells, glycohemoglobin, and relative humidity to delineate the covariant factors associated with the development of lung disease when the factors showed a significant association in the crude analysis. Data for CO were skewed and log transformed for analysis.

Table 4. Interactions among monitoring area and air pollutants.

\begin{tabular}{|c|c|c|c|c|c|c|c|c|c|c|c|c|}
\hline & \multicolumn{6}{|c|}{ Northern and Central Region } & \multicolumn{6}{|c|}{ Southern Region } \\
\hline & $\begin{array}{l}\text { Obstructive } \\
\text { vs. Normal }\end{array}$ & & $\begin{array}{l}\text { Restrictive } \\
\text { vs. Normal }\end{array}$ & & $\begin{array}{c}\text { Mixed vs. } \\
\text { Normal }\end{array}$ & & $\begin{array}{l}\text { Obstructive } \\
\text { vs. Normal }\end{array}$ & & $\begin{array}{l}\text { Restrictive } \\
\text { vs. Normal }\end{array}$ & & $\begin{array}{c}\text { Mixed vs. } \\
\text { Normal }\end{array}$ & \\
\hline & $\begin{array}{c}\text { Adjusted } \\
\text { OR (95\% CI) }\end{array}$ & $p$ & $\begin{array}{c}\text { Adjusted } \\
\text { OR (95\% CI) }\end{array}$ & $p$ & $\begin{array}{c}\text { Adjusted } \\
\text { OR }(95 \% \text { CI) }\end{array}$ & $p$ & $\begin{array}{c}\text { Adjusted } \\
\text { OR (95\% CI) }\end{array}$ & $p$ & $\begin{array}{c}\text { Adjusted } \\
\text { OR (95\% CI) }\end{array}$ & $p$ & $\begin{array}{c}\text { Adjusted } \\
\text { OR (95\% CI) }\end{array}$ & $p$ \\
\hline $\mathrm{PM}_{10}$ & $\begin{array}{c}0.99 \\
(0.98-0.00)\end{array}$ & 0.0769 & $\begin{array}{c}1.02 \\
(0.99-0.04)\end{array}$ & 0.0626 & $\begin{array}{c}1.01 \\
(0.99-1.03)\end{array}$ & 0.1390 & $\begin{array}{c}0.99 \\
(0.98-1.00)\end{array}$ & 0.1266 & $\begin{array}{c}0.96 \\
(0.94-0.99)\end{array}$ & 0.0029 & $\begin{array}{c}0.98 \\
(0.95-1.02)\end{array}$ & 0.3101 \\
\hline $\mathrm{PM}_{2.5}$ & $\begin{array}{c}0.98(0.96- \\
0.99)\end{array}$ & 0.0048 & $\begin{array}{c}1.00 \\
(0.97-0.03)\end{array}$ & 0.8962 & $\begin{array}{c}0.98 \\
(0.95-1.01)\end{array}$ & 0.2379 & $\begin{array}{c}0.97 \\
(0.96-0.99)\end{array}$ & 0.0030 & $\begin{array}{c}1.00 \\
(0.97-1.03)\end{array}$ & 0.8837 & $\begin{array}{c}0.97 \\
(0.93-1.02)\end{array}$ & 0.2641 \\
\hline $\mathrm{CO}$ & $\begin{array}{c}0.85 \\
(0.66-0.10)\end{array}$ & 0.2096 & $\begin{array}{c}1.48 \\
(0.89-0.46)\end{array}$ & 0.1276 & $\begin{array}{c}2.42 \\
(1.44-4.06)\end{array}$ & 0.0008 & $\begin{array}{c}4.17 \\
(2.08-8.37)\end{array}$ & $<0.0001$ & $\begin{array}{c}11.58 \\
(3.29-40.81)\end{array}$ & 0.0001 & $\begin{array}{c}18.85 \\
(3.53-100.59)\end{array}$ & 0.0006 \\
\hline $\mathrm{NO}$ & $\begin{array}{c}1.00 \\
(0.98-0.03)\end{array}$ & 0.7094 & $\begin{array}{c}1.03 \\
(0.99-0.08)\end{array}$ & 0.1062 & $\begin{array}{c}1.08 \\
(1.04-1.12)\end{array}$ & 0.0002 & $\begin{array}{c}1.28 \\
(1.15-1.44)\end{array}$ & $<0.0001$ & $\begin{array}{c}0.89 \\
(0.70-1.14)\end{array}$ & 0.3524 & $\begin{array}{c}1.33 \\
(1.02-1.73)\end{array}$ & 0.0349 \\
\hline $\mathrm{NO}_{2}$ & $\begin{array}{c}0.99 \\
(0.97-0.00)\end{array}$ & 0.1122 & $\begin{array}{c}1.03 \\
(0.99-0.06)\end{array}$ & 0.1903 & $\begin{array}{c}1.06 \\
(1.02-1.10)\end{array}$ & 0.0033 & $\begin{array}{c}1.13 \\
(1.08-1.18)\end{array}$ & $<0.0001$ & $\begin{array}{c}1.09 \\
(1.01-1.18)\end{array}$ & 0.0263 & $\begin{array}{c}1.25 \\
(1.13-1.37)\end{array}$ & $<0.0001$ \\
\hline $\mathrm{NO}_{x}$ & $\begin{array}{c}1.00 \\
(0.98-0.01)\end{array}$ & 0.4423 & $\begin{array}{c}1.02 \\
(0.99-0.04)\end{array}$ & 0.1333 & $\begin{array}{c}1.04 \\
(1.02-1.06)\end{array}$ & 0.0006 & $\begin{array}{c}1.09 \\
(1.06-1.13)\end{array}$ & $<0.0001$ & $10 \begin{array}{c}1.05 \\
(0.99-1.11)\end{array}$ & 0.1367 & $\begin{array}{c}1.16 \\
(1.08-1.25)\end{array}$ & $<0.0001$ \\
\hline $\mathrm{O}_{3}$ & $\begin{array}{c}1.01 \\
(0.98-0.04)\end{array}$ & 0.4920 & $\begin{array}{c}0.95 \\
(0.90-0.02)\end{array}$ & 0.1542 & $\begin{array}{c}0.89 \\
(0.83-0.95)\end{array}$ & 0.0004 & $\begin{array}{c}0.99 \\
(0.95-1.03)\end{array}$ & 0.5165 & $\begin{array}{c}1.01 \\
(0.94-1.09)\end{array}$ & 0.7119 & $\begin{array}{c}0.91 \\
(0.82-1.01)\end{array}$ & 0.0838 \\
\hline $\mathrm{SO}_{2}$ & $\begin{array}{c}0.95 \\
(0.86-0.05)\end{array}$ & 0.3577 & $\begin{array}{c}1.19 \\
(0.99-0.44)\end{array}$ & 0.0658 & $\begin{array}{c}1.34 \\
(1.10-1.63)\end{array}$ & 0.0031 & $\begin{array}{c}1.65 \\
(1.45-1.89)\end{array}$ & $<0.0001$ & $\begin{array}{c}1.29 \\
(1.00-1.65)\end{array}$ & 0.0491 & $\begin{array}{c}1.83 \\
(1.4-2.38)\end{array}$ & $<0.0001$ \\
\hline
\end{tabular}

Adjusted ORs and 95\% CIs were estimated using multinomial logistic regression after categorization by age, height, white blood cells, glycohemoglobin, and relative humidity to delineate the covariant factors associated with the development of lung disease when the factors showed a significant association in the crude analysis. Data for CO were skewed and log transformed for analysis.

\section{Discussion}

In this analysis of 2889 participants registered in the TWB, we found that factors associated with higher risk of chronic lung diseases include elderly age ( $>60$ years), female gender, lower body height and weight, higher body adiposity index and body roundness index, lower haematocrit, higher glycohemoglobin, and lower albumin level. We also assessed the synergistic effects of temperature, monitoring area and air pollutants on chronic lung diseases. The results showed a $\mathrm{V} / \mathrm{U}$-shaped relationship between temperature and air pollutants, and both lower and higher temperatures increased the risk of air pollution, but this effect was more obvious at lower temperatures and in southern Taiwan. 
Finally, we found that $\mathrm{CO}, \mathrm{NO}, \mathrm{NO}_{2}, \mathrm{NO}_{x}$, and $\mathrm{SO}_{2}$ levels were strongly associated with chronic lung diseases, while other air pollutants $\left(\mathrm{O}_{3}, \mathrm{PM}_{2.5}\right.$ and $\left.\mathrm{PM}_{10}\right)$ were not.

The first important finding of this study was that elderly age ( $>60$ years), female gender, lower body height and weight, higher body adiposity index and body roundness index, lower hematocrit, higher glycohemoglobin, and lower albumin level had the higher risk for chronic lung diseases. In addition, lower body weight and height but higher BAI means that weight is low, but body adipose tissue content is high. For example, normal weight obesity (NWO) is a term used to describe patients with higher body adiposity index but normal body weight and body mass index (BMI) [28,29]. The Towards a Revolution in COPD Health (TORCH) study showed that high-risk factors for moderate and severe COPD exacerbations were older age (patients $\geq 75$ years of age), lower body mass index $\left(\mathrm{BMI}<20 \mathrm{~kg} / \mathrm{m}^{2}\right.$ ), and female with poor baseline lung function (females had 1.42 times higher exacerbation rate than males) [30]. A study in C57BL/6J mice showed that estrogen deficiency and an increased estrogen receptor $\alpha$ expression led to the development of emphysema in aging female mouse lungs, and that these conditions improved after $17 \beta$ estradiol (E2, $0.025 \mathrm{mg}$ ) treatment [31,32]. In a study in aging female C57BL/6J mice, the absence of E2 resulted in a decrease in hydroxyproline content, macrophage number, and respiratory chain complex-1 protein, particularly in estrogen-deficient mice exposed to cigarette smoke [33]. In addition, Tian et al. reported that the effects of PM were stronger at high temperatures in elderly women, possibly due to menopause [34]. Moreover, a systematic review showed an increased rate of lung function decline and a significant risk of chronic lung diseases in menopausal women [35]. Thus, we speculate that women may be more vulnerable than men to develop chronic lung diseases upon exposure to air pollution, and that estrogen therapy may be a potential solution for aging-related lung diseases in women.

Furthermore, we found a V/U-shaped relationship between temperature and air pollutants (Figure 1), which means that, when the temperature was around $24.3-24.9{ }^{\circ} \mathrm{C}$ (optimum temperature) (Table S7), the concentration of air pollutants was at the lowest. Besides, both lower and higher temperatures increased the risk of air pollution, but this was more pronounced at lower temperatures. A previous study indicated that temperature may modify the effect of pollution exposure [36]. Moreover, a high temperature has been associated with an increase in COPD-related hospital admissions [37], and a decrease in survival of older patients with chronic lung diseases [38]. Another study showed that cold temperatures increased the COPD exacerbation rate [39]. Air pollution concentrations are continuously affected by temperature changes and are often associated with exacerbations of COPD in older patients [40]. Two previous studies demonstrated that both extremely high and low temperatures were associated with an increase in the incidence of lung diseases [41,42]. In the context of climate change, as temperatures rise and extreme weather events increase, people are paying more attention to the impact of the interaction between air pollution and meteorological factors.

Another important finding of the present study was that temperature, monitoring region, and air pollutants had a synergistic effect on chronic lung diseases. Compared with northern and central Taiwan, southern Taiwan has a serious air pollution problem, mainly due to heavy industrial and commercial activity, especially in Kaohsiung City [43]. Almost all air pollutants showed higher concentrations in southern Taiwan, where the temperature is also higher, and where there is a higher density of industrial factories (there are more than 5000 factories in Kaohsiung City). We found interactions between temperature and monitoring region, temperature and air pollution, and monitoring region and air pollution (Table S5). Thus, our results showed that people living in the southern region had a higher likelihood of being affected by serious air pollution and induced chronic lung diseases (Table 4). As a result, we assume that the synergistic reactions among temperature, monitoring region, and air pollutants are risk factors for chronic lung diseases due to the further adsorption of other pollutants. 
The last important finding of this study was that $\mathrm{CO}, \mathrm{NO}, \mathrm{NO}_{2}, \mathrm{NO}_{\mathrm{x}}$, and $\mathrm{SO}_{2}$ levels were positively correlated with the incidence of chronic lung diseases, especially at low temperatures. However, the other air pollutants $\left(\mathrm{O}_{3}, \mathrm{PM}_{2.5}\right.$, and $\left.\mathrm{PM}_{10}\right)$ were not correlated with the incidence of chronic lung diseases. The toxicity of $\mathrm{CO}$ lies in its high binding affinity for hemoglobin to produce carboxyhemoglobin, which changes the conformation of hemoglobin and reduces its ability to carry oxygen [44]. Although previous studies have shown that low concentrations of $\mathrm{CO}$ can be used as a treatment option for COPD, this method is still experimental and not routinely used in the clinical setting [45], and it is still considered to be an environmental air pollutant. A case-control study in Malawian adults found that chronic lung symptoms were associated with CO exposure (OR 1.46; 95\% CI 1.04-2.05) [46]. Inhaled NO therapy can be used to treat adult respiratory distress syndrome, primary pulmonary hypertension, and chronic obstructive pulmonary disease [47]. However, a review in the Cochrane database reported that inhalation of nitric oxide may temporarily increase oxygenation level, but it is not statistically significant for one-month survival [48]. In addition, $\mathrm{NO}_{2}$ has been demonstrated to trigger an inflammatory response, including in vitro and in vivo increases in interleukin-8 (IL-8) concentrations [49]. Furthermore, increased systemic and sputum IL-8 concentrations have been associated with COPD exacerbations [50]. Ambient $\mathrm{NO}_{2}$ can intensify allergic inflammatory reactions in the airways without causing symptoms or pulmonary dysfunction [51]. Jiang et al. reported that, with an increase of $10 \mathrm{ppb}$ in $\mathrm{NO}_{2}$, the predicted values of FVC and FEV1 decreased by $0.12 \%$ and $0.37 \%$, respectively, on the second day [52]. Besides, Duan et al. revealed that with an increase of $10 \mathrm{ppb}$ in $\mathrm{NO}_{2}$ in the cold season, the daily mortality rate increases by $4.45 \%$ within a lag time of 0 to 2 days [53]. Goudarzi et al. reported that $\mathrm{SO}_{2}$ is mostly produced by exhaust gas discharged from industrial production processes, and that it eventually leads to deterioration of the surrounding air quality [54]. An animal study demonstrated activation of the TLR4/p38/NF-kB pathway accompanied by excessive secretion of pro-inflammatory cytokines in the lungs of rats exposed to $\mathrm{PM}_{2.5}$ and $\mathrm{SO}_{2}$, indicating inflammatory, pathological, and ultrastructural damage [55]. Taken together, we suggest that $\mathrm{CO}, \mathrm{NO}, \mathrm{NO}_{2}, \mathrm{NO}_{\mathrm{x}}$, and $\mathrm{SO}_{2}$ cause chronic lung diseases through inflammation, and that high ambient concentrations of $\mathrm{CO}, \mathrm{NO}, \mathrm{NO}_{2}, \mathrm{NO}_{\mathrm{x}}$, and $\mathrm{SO}_{2}$ are possible risk factors for chronic lung diseases. The average level of $\mathrm{O}_{3}$ in this study was lower than the world average [56], and therefore its impact on lung diseases might not be obvious. In addition, $\mathrm{O}_{3}$ levels had the opposite effect to other air pollutants (such as $\mathrm{NO}_{\mathrm{x}}$ ) in this study, which is consistent with a previous study [57]. A possible explanation is that $\mathrm{NO}_{\mathrm{x}}$ and volatile organic compounds react and combine under ultraviolet light to form ground-level $\mathrm{O}_{3}$ [58]. Therefore, when the $\mathrm{NO}_{x}$ concentration drops, the $\mathrm{O}_{3}$ concentration will gradually increase. Although, there was no obvious relationship between $\mathrm{PM}_{2.5}, \mathrm{PM}_{10}$ and chronic lung disease in this study, a previous study has pointed out that the concentration of PM increases with temperature, and thus the impact of $\mathrm{PM}_{2.5}$ on lung diseases may only occur at higher temperatures [59]. In addition, a study showed that hospital admission rates for respiratory diseases increased with increasing PM and temperature [24]. Our data was consistent with the above study result. Furthermore, it is possible that the lack of association between $\mathrm{PM}_{2.5}$ and $\mathrm{PM}_{10}$ and the incidence of chronic lung diseases in this study may be due to the level of exposure not being high enough or the duration of exposure not being long enough.

To the best of our knowledge, this is the first study to comprehensively investigate the association between chronic lung diseases (classified by lung function) and air pollution, meteorological factors, and anthropometric indices. The novelty of this study is that we found a V/U-shaped relationship between temperature and air pollutants, which means that when the temperature is around $24.3-24.9{ }^{\circ} \mathrm{C}$ (optimum temperature), the concentration of air pollutants is at the lowest. However, there are also several limitations to this study. First, this is a cross-sectional study; therefore, we could not assess the relationship between air pollution and the progression of lung function over time or the occurrence of chronic lung diseases. A follow-up cohort study is needed to confirm the 
results. Second, we used lung function assessments to identify chronic lung diseases. However, we could not obtain follow-up lung function data or imaging studies to confirm the progression of disease. Third, we used the participants' residential address as the air pollutant exposure point. However, this is a rough measurement of air pollution exposure, and it may not accurately reflect the actual personal exposure. In addition, we did not have information regarding indoor air quality. Lung function can also be influenced by exposure to indoor air pollutants (such as brominated diphenyl-ethers, polychlorinated biphenyls [60], volatile organic compounds, polycyclic aromatic hydrocarbons, $\mathrm{PM}_{2.5}$ (cigarette smoke, and cooking) [61]. This will be an important topic for further study. Finally, the Taiwan Biobank does not contain information regarding occupational exposure to toxic substances, and therefore this variable cannot be analyzed in this study.

In conclusion, when compared with the normal spirometry group, we found that factors associated with higher risk of chronic lung diseases include elderly age ( $>60$ years), female gender, lower body weight and height, higher BAI and BRI, lower haematocrit, lower albumin level, and higher glycohemoglobin level (Table 1). We also observed interactions and synergistic effects among temperature, air pollutants and different monitoring regions. Furthermore, both high and low temperatures, and exposure to various air pollutants including $\mathrm{CO}, \mathrm{NO}, \mathrm{NO}_{2}, \mathrm{NO}_{\mathrm{x}}$ and $\mathrm{SO}_{2}$ have strong impacts on the development of chronic lung diseases, especially at low temperatures $\left(<24.6^{\circ} \mathrm{C}\right)$ and in heavy industrial regions such as southern Taiwan. This study highlights the importance of air pollution in chronic lung diseases. We suggest that temperature and air pollution should be considered together when evaluating the impact on chronic lung diseases.

Supplementary Materials: The following are available online at https:/ /www.mdpi.com/article/10 .3390/jpm11080819/s1, Table S1: Multiple comparison tests (post hoc analysis), Table S2: Descriptive statistics of air pollutants and meteorological factors, Table S3: Pearson product-moment correlations to measure the relationships between air pollutants, Table S4: Multinomial logistic regression analysis, Table S5: Interaction terms (cross-product terms), Table S6: Effect modification (interaction) associations between monitoring regions and temperature, Table S7: Descriptive statistics of air pollutants divided by turning point temperature in the four lung function groups and monitoring regions in the four lung function groups.

Author Contributions: P.-S.C. \& S.-C.C.: Conceptualization, Supervision. D.-W.W.: Writing-original draft, Formal analysis. H.-P.T.: Methodology, Supervision. C.-W.W.: Investigation, Formal analysis. C.-H.H.: Investigation, Supervision. H.-C.C.: Writing—review \& editing. T.-Y.K.: Writing—review \& editing. B.-C.L.: Writing—review \& editing. C.-F.W.: Writing-review \& editing. C.-H.K.: Supervision. All authors have read and agreed to the published version of the manuscript.

Funding: This work was supported partially by the Research Center for Environmental Medicine, Kaohsiung Medical University, Kaohsiung, Taiwan from The Featured Areas Research Center Program within the framework of the Higher Education Sprout Project by the Ministry of Education (MOE) in Taiwan and by Kaohsiung Medical University Research Center Grant (KMU-TC109A01-1), and Kaohsiung Municipal Siaogang Hospital (S-109-04).

Institutional Review Board Statement: The study was conducted according to the guidelines of the Declaration of Helsinki and approved by the Institutional Review Board of Kaohsiung Medical University Chung-Ho Memorial Hospital (KMUHIRB-E(I)-20180242) and 2018/8/3 approval.

Informed Consent Statement: Informed consent was not required since this is a retrospective study using a national database. However, informed consent was obtained from all subjects who were included in the TWB.

Data Availability Statement: The data underlying this study is from the Taiwan Biobank. Due to restrictions placed on the data by the Personal Information Protection Act of Taiwan, the minimal data set cannot be made publicly available. Data may be available upon request to interested researchers. Please send data requests to: Szu-Chia Chen, Division of Nephrology, Department of Internal Medicine, Kaohsiung Medical University Hospital, Kaohsiung Medical University.

Conflicts of Interest: The authors declare no conflict of interest. 


\section{References}

1. Miller, M.R.; Hankinson, J.; Brusasco, V.; Burgos, F.; Casaburi, R.; Coates, A.; Crapo, R.; Enright, P.; van der Grinten, C.P.; Gustafsson, P.; et al. Standardization of spirometry. Eur. Respir. J. 2005, 26, 319-338. [CrossRef] [PubMed]

2. Doiron, D.; Hoogh, K.; Probst-Hensch, N.; Fortier, I.; Cai, Y.; Matteis, S.D.; Hansell, A.L. Air pollution, lung function and COPD: Results from the population-based UK Biobank study. Eur. Respir. J. 2019, 54, 1802140. [CrossRef] [PubMed]

3. Adam, M.; Schikowski, T.; Carsin, A.E.; Cai, Y.; Jacquemin, B.; Sanchez, M.; Vierkötter, A.; Marcon, A.; Keidel, D.; Sugiri, D.; et al. Adult lung function and long-term air pollution exposure. ESCAPE: A multicenter cohort study and meta-analysis. Eur. Respir. J. 2005, 45, 38-50. [CrossRef]

4. Jong, K.; Vonk, J.; Zijlema, W. Air pollution exposure is associated with restrictive ventilatory patterns. Eur. Respir. J. 2016, 48, 1221-1224. [CrossRef]

5. Atkinson, R.W.; Carey, I.M.; Kent, A.J.; Staa, T.P.; van Anderson, H.R.; Cook, D.G. Long-term exposure to outdoor air pollution and the incidence of chronic obstructive pulmonary disease in a national English cohort. Occup. Environ. Med. 2015, 72, 42-48. [CrossRef]

6. Jiang, X.-Q.; Me, X.-D.; Feng, D. Air pollution and chronic airway diseases: What should people know and do? J. Thorac. Dis. 2016, 8, E31.

7. Sangkharat, K.; Fisher, P.; Thomas, G.N.; Thornes, J.; Pope, F.D. The impact of air pollutants on ambulance dispatches: A systematic review and meta-analysis of acute effects. Environ. Pollut. 2019, 254, 112769. [CrossRef]

8. Sanyal, S.; Rochereau, T.; Maesano, C.N.; Com-Ruelle, L.; Annesi-Maesano, I. Long-Term Effect of Outdoor Air Pollution on Mortality and Morbidity: A 12-Year Follow-Up Study for Metropolitan France. Int. J. Environ. Res. Public Health 2018, 15, 2487. [CrossRef]

9. Dong, G.-H.; Zhang, P.; Sun, B.; Zhang, L.; Chen, X.; Ma, N.; Yu, F.; Guo, H.; Huang, H.; Lee, Y.-L.; et al. Long-Term Exposure to Ambient Air Pollution and Respiratory Disease Mortality in Shenyang, China: A 12-Year Population-Based Retrospective Cohort Study. Respiration 2012, 84, 360-368. [CrossRef]

10. To, T.; Feldman, L.; Simatovic, J.; Gershon, A.S.; Dell, S.; Su, J.; Foty, R.; Licskai, C. Health risk of air pollution on people living with major chronic diseases: A Canadian population-based study. BMJ Open 2015, 5, e009075. [CrossRef]

11. Valenti, C.; Pozzi, P.; Busia, A.; Mazza, R.; Bossi, P.; Marco, C.D.; Ruprecht, A.A.; Borgini, A.; Boffi, R. Respiratory illness and air pollution from the steel industry: The case of Piquiá de Baixo, Brazil (Preliminary report). Multidiscip. Respir. Med. 2016, 11, 41-48. [CrossRef] [PubMed]

12. Falcon-Rodriguez, C.I.; Osornio-Vargas, A.R.; Sada-Ovalle, I.; Segura-Medina, P. Aeroparticles, Composition, and Lung Diseases. Front. Immunol. 2016, 7, 3. [CrossRef] [PubMed]

13. Kim, K.-H.; Kabir, E.; Kabir, S. A review on the human health impact of airborne particulate matter. Environ. Int. 2015, 74, 136-143. [CrossRef] [PubMed]

14. Møller, P.; Loft, S. Oxidative damage to DNA and lipids as biomarkers of exposure to air pollution. Environ. Health Perspect. 2010, 118, 1126-1136. [CrossRef] [PubMed]

15. Bind, M.A.; Baccarelli, A.; Zanobetti, A.; Tarantini, L.; Suh, H.; Vokonas, P.; Schwartz, J. Air pollution and markers of coagulation, inflammation and endothelial function: Associations and epigene-environment interactions in an elderly cohort. Epidemiology 2012, 23, 332. [CrossRef]

16. Paulin, L.; Hansel, N. Particulate air pollution and impaired lung function. F1000Research 2016, 5, F1000. [CrossRef] [PubMed]

17. Sun, X.-W.; Chen, P.-L.; Ren, L.; Lin, Y.-N.; Zhou, J.-P.; Ni, L.; Li, Q.-Y. The cumulative effect of air pollutants on the acute exacerbation of COPD in Shanghai, China. Sci. Total Environ. 2018, 622, 875-881. [CrossRef]

18. Sun, Q.; Liu, C.; Chen, R.; Wang, C.; Li, J.; Sun, J.; Kan, H.; Cao, J.; Bai, H. Association of fine particulate matter on acute exacerbation of chronic obstructive pulmonary disease in Yancheng, China. Sci. Total Environ. 2019, 650, 1665-1670. [CrossRef]

19. Abramson, M.J.; Wigmann, C.; Altug, H.; Schikowski, T. Ambient air pollution is associated with airway inflammation in older women: A nested cross-sectional analysis. BMJ Open Respir. Res. 2020, 7, e000549. [CrossRef]

20. Yu, H.-R.; Lin, C.-H.; Tsai, J.-H.; Hsieh, Y.-T.; Tsai, T.-A.; Tsai, C.-K.; Lee, Y.-C.; Liu, T.-Y.; Tsai, C.-M.; Chen, C.-C.; et al. A multifactorial evaluation of the effects of air pollution and meteorological factors on asthma exacerbation. Int. J. Environ. Res. Public Health 2020, 17, 4010. [CrossRef]

21. Lee, W.; Choi, H.M.; Kim, D.; Honda, Y.; Guo, Y.-L.L.; Kim, H. Synergic effect between high temperature and air pollution on mortality in Northeast Asia. Environ. Res. 2019, 178, 108735. [CrossRef] [PubMed]

22. Analitis, A.; Donato, F.D.; Scortichini, M.; Lanki, T.; Basagana, X.; Ballester, F.; Astrom, C.; Paldy, A.; Pascal, M.; Gasparrini, A.; et al. Synergistic Effects of Ambient Temperature and Air Pollution on Health in Europe: Results from the PHASE Project. Int. J. Environ. Res. Public Health 2018, 15, 1856. [CrossRef] [PubMed]

23. Hansel, N.N.; McCormack, M.C.; Kim, V. The Effects of Air Pollution and Temperature on COPD. COPD: J. Chronic Obstr. Pulm. Dis. 2016, 13, 372-379. [CrossRef] [PubMed]

24. Jo, E.-J.; Lee, W.-S.; Jo, H.-Y.; Kim, C.-H.; Eom, J.-S.; Mok, J.-H.; Kim, M.-H.; Lee, K.; Kim, K.-U.; Lee, M.-K.; et al. Effects of particulate matter on respiratory disease and the impact of meteorological factors in Busan, Korea. Respir. Med. 2017, 124, 79-87. [CrossRef] 
25. Chen, C.-H.; Yang, J.-H.; Chiang, C.W.K.; Hsiung, C.-N.; Wu, P.-E.; Chang, L.-C.; Chu, H.-W.; Chang, J.; Song, I.W.; Yang, S.-L.; et al. Population structure of Han Chinese in the modern Taiwanese population based on 10,000 participants in the Taiwan Biobank project. Hum. Mol. Genet. 2016, 25, 5321-5331. [CrossRef]

26. Lin, J.-C.; Hsiao, W.W.-W.; Fan, C.-T. Managing "incidental findings" in biobank research: Recommendations of the Taiwan biobank. Comput. Struct. Biotechnol. J. 2019, 17, 1135-1142. [CrossRef]

27. Hsieh, S.W.; Wu, D.W.; Wang, C.W.; Chen, S.C.; Hung, C.H.; Kuo, C.H. Poor cognitive function is associated with obstructive lung diseases in Taiwanese adults. Int. J. Environ. Res. Public Health 2021, 18, 2344. [CrossRef]

28. Oliveros, E.; Somers, V.; Sochor, O.; Goel, K.; Lopez-Jimenez, F. The concept of normal weight obesity. Prog. Cardiovasc. Dis. 2014, 56, 426-433. [CrossRef]

29. Alvarez, J.A.; Ziegler, T.R.; Millson, E.C.; Stecenko, A.A. Body composition and lung function in cystic fibrosis and their association with adiposity and normal-weight obesity. Nutrition 2016, 32, 447-452. [CrossRef]

30. Jenkins, C.R.; Celli, B.; Anderson, J.A.; Ferguson, G.T.; Jones, P.W.; Vestbo, J.; Yates, Y.C.; Calverley, P.M.A. Seasonality and determinants of moderate and severe COPD exacerbations in the TORCH study. Eur. Respir. J. 2012, 39, 38-45. [CrossRef]

31. Huang, K.; Rabold, R.; Schofield, B.; Mitzner, W.; Tankersley, C.G. Age dependent changes of airway and lung parenchyma in C57BL/6J mice. J. Appl. Physiol. 2007, 102, 200-206. [CrossRef]

32. Glassberg, M.K.; Choi, R.; Manzoli, V.; Shahzeidi, S.; Rauschkolb, P.; Voswinckel, R.; Aliniazee, M.; Xia, X.; Elliot, S.J. 17ß-Estradiol replacement reverses age-related lung disease in estrogen-deficient C57BL/6J mice. Endocrinology 2014, 155, 441-448. [CrossRef]

33. Glassberg, M.K.; Catanuto, P.; Shahzeidi, S.; Aliniazee, M.; Lilo, S.; Rubio, G.A.; Elliot, S.J. Estrogen deficiency promotes cigarette smoke-induced changes in the extracellular matrix in the lungs of aging female mice. Transl. Res. 2016, 178, 107-117. [CrossRef]

34. Tian, L.; Liang, F.; Guo, Q.; Shi, C.; Xiao, S.; Wu, Z.; Jin, X.; Pan, X. The effects of interaction between particulate matter and temperature on mortality in Beijing, China. Environ. Sci. Process. Impacts 2018, 20, 395-405. [CrossRef] [PubMed]

35. Campbell, B.; Davis, S.R.; Abramson, M.J.; Mishra, G.; Handelsman, D.J.; Perret, J.L.; Dharmage, S.C. Menopause, lung function and obstructive lungdisease outcomes: A systematic review. Climacteric 2018, 21, 3-12. [CrossRef] [PubMed]

36. Li, J.; Woodward, A.; Hou, X.-Y.; Zhu, T.; Zhang, J.; Brown, H.; Yang, J.; Qin, R.; Gao, J.; Gu, S.; et al. Modification of the effects of air pollutants on mortality by temperature: A systematic review and meta-analysis. Sci. Total Environ. 2017, 575, 1556-1570. [CrossRef]

37. Lin, S.; Luo, M.; Walker, R.J.; Liu, X.; Hwang, S.-A.; Chinery, R. Extreme high temperatures and hospital admissions for respiratory and cardiovascular diseases. Epidemiology 2009, 20, 738-746. [CrossRef]

38. Zanobetti, A.; O’Neill, M.S.; Gronlund, C.J.; Schwartz, J.D. Summer temperature variability and long-term survival among elderly people with chronic disease. Proc. Natl. Acad. Sci. USA 2012, 109, 6608-6613. [CrossRef] [PubMed]

39. Tseng, C.-M.; Chen, Y.-T.; Ou, S.-M.; Hsiao, Y.-H.; Li, S.-Y.; Wang, S.-J.; Yang, A.C.; Chen, T.-J.; Perng, D.-W. The effect of cold temperature on increased exacerbation of chronic obstructive pulmonary disease: A nationwide study. PLoS ONE 2013, 8, e57066. [CrossRef] [PubMed]

40. Lin, M.-T.; Kor, C.-T.; Chang, C.-C.; Chai, W.-H.; Soon, M.-S.; Ciou, Y.-S.; Lian, I.B.; Chang, C.C. Association of meteorological factors and air $\mathrm{NO}_{2}$ and $\mathrm{O}_{3}$ concentrations with acute exacerbation of elderly chronic obstructive pulmonary disease. Sci. Rep. 2018, 8, 10192. [CrossRef] [PubMed]

41. Chai, G.; He, H.; Su, Y.; Sha, Y.; Zong, S. Lag effect of air temperature on the incidence of respiratory diseases in Lanzhou, China. Int. J. Biometeorol. 2020, 64, 83-93. [CrossRef]

42. Breitner, S.; Wolf, K.; Devlin, R.B.; Diaz-Sanchez, D.; Peters, A.; Schneider, A. Short-term effects of air temperature on mortality and effect modification by air pollution in three cities of Bavaria, Germany: A time-series analysis. Sci. Total Environ. 2014, 485, 49-61. [CrossRef]

43. Cheng, M.-H.; Chiu, H.-F.; Yang, C.-Y. Coarse particulate air pollution associated with increased risk of hospital admissions for respiratory diseases in a tropical city, Kaohsiung, Taiwan. Int. J. Environ. Res. Public Health 2015, 12, 13053-13068. [CrossRef] [PubMed]

44. Veronesi, A.; Pecoraro, V.; Zauli, S.; Ottone, M.; Leonardi, G.; Lauriola, P.; Trenti, T. Use of carboxyhemoglobin as a biomarker of environmental CO exposure: Critical evaluation of the literature. Environ. Sci. Pollut. Res. Int. 2017, 24, 25798-25809. [CrossRef] [PubMed]

45. Hess, D.R. Inhaled Carbon Monoxide: From Toxin to Therapy. Respir. Care. 2017, 62, 1333-1342. [CrossRef]

46. Nightingale, R.; Lesosky, M.; Flitz, G.; Rylance, S.J.; Meghji, J.; Burney, P.; Balmes, J.; Mortimer, K. Noncommunicable respiratory disease and air pollution exposure in Malawi. Am. J. Respir. Crit. Care Med. 2019, 199, 613-621. [CrossRef]

47. Marriott, H.; Higenbottam, T. The role of nitric oxide in respiratory disease. Schweiz. Med. Wochenschr. 1997, 127, 709-714.

48. Gebistorf, F.; Karam, O.; Wetterslev, J.; Afshari, A. Inhaled nitric oxide for acute respiratory distress syndrome (ARDS) in children and adults. Cochrane Database Syst. Rev. 2016, 6, CD002787. [CrossRef]

49. Dadvand, P.; Nieuwenhuijsen, M.J.; Agust, À.; Batlle, J.; Benet, M.; Beelen, R.; Cirach, M.; Martinez, D.; Hoek, F.; Basagaña, X.; et al. Air pollution and biomarkers of systemic inflammation and tissue repair in COPD patients. Eur. Respir. J. 2014, 44, 603-613. [CrossRef]

50. Liu, H.-C.; Lu, M.-C.; Lin, Y.-C.; Wu, T.-C.; Hsu, J.-Y.; Jan, M.-S.; Chen, C.-M. Differences in IL-8 in serum and exhaled breath condensate from patients with exacerbated COPD or asthma attacks. J. Formos. Med. Assoc. 2014, 113, 908-914. [CrossRef] 
51. Barck, C.; Sandström, T.; Lundahl, J.; Halldén, G.; Svartengren, M.; Strand, V.; Rak, S.; Bylin, G. Ambient level of NO2 augments the inflammatory response to inhaled allergen in asthmatics. Respir. Med. 2002, 96, 907-917. [CrossRef] [PubMed]

52. Jiang, Y.; Niu, Y.; Xia, Y.; Liu, C.; Lin, Z.; Wang, W.; Ge, Y.; Lei, X.; Wang, C.; Cai, J.; et al. Effects of personal nitrogen dioxide exposure on airway inflammation and lung function. Environ. Res. 2019, 177, 108620. [CrossRef] [PubMed]

53. Duan, Y.; Liao, Y.; Li, H.; Yan, S.; Zhao, Z.; Yu, S.; Zhao, Z.; Yu, S.; Fu, Y.; Wang, Z.; et al. Effect of changes in season and temperature on cardiovascular mortality associated with nitrogen dioxide air pollution in Shenzhen, China. Sci. Total Environ. 2019, 697, 134051. [CrossRef] [PubMed]

54. Goudarzi, G.; Geravandi, S.; Idani, E.; Hosseini, S.A.; Baneshi, M.M.; Yari, A.R.; Dobaradaran, S.; Shirali, S.; Marzooni, B.B.; Ghomeishi, A.; et al. An evaluation of hospital admission respiratory disease attributed to sulfur dioxide ambient concentration in Ahvaz from 2011 through 2013. Environ. Sci. Pollut. Res. Int. 2016, 23, 22001-22007. [CrossRef] [PubMed]

55. Li, R.; Zhao, L.; Tong, J.; Yan, Y.; Xu, C. Fine particulate matter and sulfur dioxide coexposures Induce Rat Lung Pathological Injury and Inflammatory Responses Via TLR4/p38/NF-кB Pathway. Int. J. Toxicol. 2017, 36, 165-173. [CrossRef]

56. Malley, C.S.; Henze, D.K.; Kuylenstierna, J.C.I.; Vallack, H.W.; Davila, Y.; Anenberg, S.C.; Turner, M.C.; Ashmore, M.R. Updated Global Estimates of Respiratory Mortality in Adults $\geq 30$ Years of Age Attributable to Long-Term Ozone Exposure. Environ. Health Perspect. 2017, 125, 087021. [CrossRef]

57. Ou, J.; Zheng, J.; Li, R.; Huang, X.; Zhong, Z.; Zhong, L.; Lin, H. Speciated OVOC and VOC emission inventories and their implications for reactivity-based ozone control strategy in the Pearl River Delta region, China. Sci. Total Environ. 2015, 530, 393-402. [CrossRef] [PubMed]

58. Zhang, J.J.; Wei, Y.; Fang, Z. Ozone Pollution: A Major Health Hazard Worldwide. Front. Immunol. 2019, 10, 2518. [CrossRef]

59. Li, Y.; Ma, Z.; Zheng, C.; Shang, Y. Ambient temperature enhanced acute cardiovascular-respiratory mortality effects of PM2.5 in Beijing, China. Int. J. Biometeorol. 2015, 59, 1761-1770. [CrossRef]

60. Zhang, X.; Diamond, M.L.; Robson, M.; Harrad, S. Sources, emissions, and fate of polybrominated diphenyl ethers and poly chlorinated biphenyls indoors in Toronto, Canada. Environ. Sci. Technol. 2011, 45, 3268-3274. [CrossRef] [PubMed]

61. Vardoulakis, S.; Giagloglou, E.; Steinle, S.; Davis, A.; Sleeuwenhoek, A.; Galea, K.S.; Dixon, K.; Crawford, J.O. Indoor Exposure to Selected Air Pollutants in the Home Environment: A Systematic Review. Int. J. Environ. Res. Public Health 2020, $17,8972$. [CrossRef] [PubMed] 